\title{
Impact of Corporate Social Responsibility (CSR) Practices on Consumer Behavior (with Reference to FMCGs in Tamil Nadu)
}

\author{
Desti Kannaiah $^{1}$ \& A. Jayakumar ${ }^{2}$ \\ ${ }^{1}$ Senior Lecturer, School of Business, James Cook University, Singapore \\ ${ }^{2}$ Periyar University, Salem India \\ Correspondence: Desti Kannaiah, Senior Lecturer, School of Business, James Cook University, Singapore. \\ E-mail: kannaiah.desti@jcu.edu.au
}

Received: December 17, 2017

Accepted: January 18, 2018

Online Published: February 25, 2018

doi:10.5539/ijbm.v13n3p28

URL: https://doi.org/10.5539/ijbm.v13n3p28

\begin{abstract}
Business enterprises are traditionally known as engines for driving the economic performance of an entity, its success being measured in terms of high returns on equity and its contribution to the development of the society. The business enterprises get everything from the society for its survival and it is the obligation of the enterprise to return positive attitudes towards the society. If it fails to meet the expectations of the society, the society will punish the firm through their purchase behavior. Hence, the success of any business enterprise depends mainly on the ethical behavior of the enterprise towards the society. The Indian Government has made mandatory the CSR provisions and almost all the companies are actively engage in CSR activities. Fast Moving Consumer Goods (FMGCs) are the fastest growing industry in India and numbers of FMCGs companies are doing different CSR practices. Hence, it is essential to study about the impact of Corporate Social Responsibility practices on consumer behavior with reference to FMCGs in Tamil Nadu. For this, 600 responses were collected from selected corporations in TamilNadu by a structured questionnaire. Convenience sampling technique has been adopted to collect the primary data. The study concluded that there has been a positive impact among the consumers as the consumers in Tamil Nadu considered CSR in their purchase evaluation criteria, and they give much importance to CSR related products etc.
\end{abstract}

Keywords: Impact of CSR, consumer behaviour, consumers purchase decision, FMCGs

\section{Introduction}

India is a country of myriad contradictions. On the one hand, it has grown to be one of the largest economies in the world, on the other hand, it is still home to the largest number of people living in absolute poverty. Business enterprises are traditionally known as engines for driving the economic performance of an entity, its success being measured in terms of high returns on equity and its contribution to the development of the society. The business enterprises get everything from the society for its survival and it is the obligation of the enterprise to return positive attitudes towards the society.

\subsection{Corporate Social Responsibility}

Corporate Social Responsibility is the ethical behaviour of the company towards the society. It describes the corporate activities beyond profit-making. It involves not just the products that a company manufactures but also being a good corporate citizen in terms of the employees.

\subsection{CSR - Indian Perspective}

Corporate Social Responsibility for sustainable development has been adopted by corporate in India and they carry on Corporate Social Responsibility activities in education, health, skill development and needy help for weaker sections of the society. The leading corporate involved are Tata Group, Infosys, Bharti enterprises, ITC, Welcome Group, Indian Oil corporation. India is placed in the top ten ranks in disclosing Corporate Social Responsibility Tata Group and India-based indigenous multinational enterprise with a unique 140-year old commitment to the community is the pioneer in India for CSR activities. 


\subsection{Importance of the Study}

CSR has grown in importance in recent years, because of public scandals and mis-management. Corporate Social Responsibility has become mandatory in India and India is the country which has legal provisions for the Corporate Social Responsibility. Since the concept of CSR is now widely recognized by the public, many Companies both public and private actively engage in CSR activities. At this juncture, it is essential to find out whether it has made any impact among the different stakeholders of the society especially, the important stakeholder, "the consumer".

\subsection{Statement of the Problem}

The demand from the consumers in terms of CSR has been increasing. Corporate Social Responsibility activities must be made for effective by improving their consumer Social Responsibility. The Fast Moving Consumer Goods (FMCG) sector is one of the fastest growing sectors of the Indian economy. It stands first in doing CSR activities in India. Almost all FMCG companies are actively engaged in CSR practices such as Healthcare, Education, Community Welfare, Environment, Rural Development, Disaster Relief, Animal Welfare, Women Empowerment, Sports Promotion etc. A major change in the activities of FMCG companies

\subsection{Objectives of the Study}

\section{The main objectives of the study are}

- To identify the FMCGs consumers choice and awareness on CSR.

To study the influence of Demographic and the purchase details of FMCGs consumers on their CSR perception.

\subsection{Research Methodology}

It is based on the survey method.

\subsubsection{Population Identified}

The population for this research is the consumers of FMCG companies' in Tamil Nadu and the consumers should have knowledge about CSR.

\subsubsection{Nature of Data}

primary data were collected from a well-structured questionnaire and secondary data were collected from websites and annual reports of respective FMCG companies and also information collected from various Books, Newspapers, Journals, Theses and Dissertations, etc.,

\subsubsection{Sampling Design}

People who know about CSR and who are the users of FMCG products/brands are the respondents of the study. Since, the population is infinite as the users of FMCGs in Tamil Nadu are vast; a Convenience Sampling Technique was used to select the respondents. The sample consists of 600 responses collected from all the 5 corporations viz Chennai, Coimbatore, Salem, Tiruppur and Erode of Tamil Nadu. First 150 questionnaires were issued in each above mentioned five Corporations. Out of which, 677 questionnaires were received, 73 questionnaires were not received, 77 questionnaires were rejected due to invalidity of the Data and finally 600 questionnaires were found valid for the analysis purposes. The corporations were selected for the study on the basis of population and its inception viz highest, middle and lowest.

\section{Review of Literature}

This study presents the Review of Literature relating to Corporate Social Responsibility and Consumer Behaviour was discussed in this chapter. From the reviews, various measures relating to Corporate Social Responsibility relating to Consumer Behaviour were identified and incorporated in this study. The measures such as Consumer perceptions towards CSR motives, Brand Identification, Corporate Reputation; Purchase Decision measures such as Boycott and Boycott; Satisfaction, Trust and Loyalty were identified with the help of the Literature.

The important reviews are given below;

Tillmann Wagner, Richard J. Lutz, \& Barton A. Weitz (2009), In this paper the authors examined the consumer perception and beliefs about Social Responsibility and in considerable may be mitigated by effective communication. The consumer attitudes about Corporate Social Responsibility negatively affected their belief and evidences could be tried through information processing. 
Lei Wang and Heikki Juslin (2011), in this paper the authors determined the effects of personal values on individual perceptions of CSR issues. The authors investigated 980 Chinese young people. Chinese youth had negative perceptions of corporate social performance of corporations in China, mainly on the environmental dimension. In contrast, those who value self-enhancement or conservation more have more positive perceptions.

Dale W. Russell and Cristel Antonia Russell (2010), this research examined how consumers reacted to corporate social responsibility (CSR) programs that vary in geographic focus. Consumers stated that they approve of what a company is doing elsewhere but this did not necessarily increase their purchasing of the company's products

Shruti Gupta (2011), this paper examined the perception of corporate social responsibility held by consumers in India and America in order to draw out similarities and differences in conceptualization and response. The main findings of the study was that there was a substantial portion of US consumers who were unaware of socially responsible companies compared with their Indian counterparts who failed to recognize the CSR initiatives of multinational companies.

Elias G. Rizkallah (2012), in this paper, the author opined that companies are claiming that they are being challenged to maintain profitability and behave in socially responsible ways. The study has been attempted to answer these questions and more. The survey included a random sample of 317 adult individual consumers in the Southern California region

Simona Romani, Silvia Grappi and Richard P. Bagozzi (2012), in this paper, the authors analysed the role of gratitude as a missing mediator facilitating the effects of CSR on relational consumer behavior. They conducted a field experiment with adult consumers. Two classes of consumer reactions were considered: intentions to i) say positive things about the company, and ii) participate in advocacy actions benefiting the company. They concluded that some specific individual difference factors can influence consumers' feelings of gratitude and consequent behaviours, thus providing managers with tools they can use to leverage their CSR investments.

Percy Marquina Feldman and Arturo Z. Vasques-Parraga (2013), this research is the comparative effects of CSR initiatives and CA in the consumer purchasing behaviour in two countries (USA and Peru) in the shoe industry. The main results of the study demonstrated that some CSR initiatives such as companies' environmental commitments, along with some $\mathrm{CA}$, such as product quality significantly explain the nature of consumer responses and a trade-off effect on consumers' willingness to pay for a product.

Alan Pomering and Sara Dolnicar (2009), in this paper, the authors investigated the CSR - consumer relationship. This study examined the Australian banking sector, which engages in and promotes its CSR activities, to help fill this gap. Consumer understanding of many of the social issues banks engage with is also low.

Matthew Walker, Aubrey Kent (2009), the authors examined the relationship between CSR activities and fans' assessment of reputation and patronage intentions. Fans of two NFL teams are sampled. A conceptual model had been framed suggesting that the independent variable CSR with four domains i.e., Philanthropy, community involvement and youth programs in both education and health. The findings indicated that CSR had an important strategic role to play for sport organizations.

SankarSen and C.B. Bhattacharya (2001) this paper concluded that the focuses by the company on CSR are considered to be the key moderation. CSR initiative may even decrease consumer indention to buy the products more specifically; the authors found that CSR initiatives can, under certain conditions, decrease consumers' intentions to buy a company's products.

Celso Augusto de Matos and Carlos Alberto Vargas Rossi (2007),

they pointed out in their research that in consumer judgements are based on CSR activities. Results indicated first the product judgement was significantly affected by corporate social responsibility (CSR), blame attributed to the company and whether or not consumers had a car made by the brand considered; second the behavioural intentions were significantly affected by CSR, consumers' involvement with the message, perceived danger, product judgement and whether or not consumers had a car made by the brand considered.

Daniela Abrantes Ferreira, Marcos Goncalves Avila and Marina Dias de Faria (2010), the study indicated that Social Responsible firms the consumer perceived benefit and value. The study indicated that companies have the opportunity to respond to their consumers' desires of feeling good about a purchase, while achieving their business goals and simultaneously, giving their own contribution to society.

Chieh-Peng Lin, Shwu-Chuan Chen, Chou-Kang Chui and Wan-Yu Lee (2011), this article explained a company's product-harm crises often lead to negative publicity which substantially affects purchase intention. The main findings of the study showed that purchase intention is indirectly improved by strengthened CA and 
CSR. By understanding both antecedents, mediators and moderators of purchase intention in depth, management can learn to tailor a variety of corporate policies or programs to meet customers' preferences in order to increase their purchase intention.

Melissa D. Dodd, and Dustin W. Supa (2011), the authors pointed out that Consumer purchase intention recognise the relationship with CSR. The study showed that consumers are more likely to purchase products from socially responsible businesses, and therefore, businesses should seek to implement and promote CSR activities, and many participants in this study agreed, indicating that CSR was an important, necessary business activity aimed at genuinely responsible business practices

Alka Sharma and Shelleka Gupta (2012), in this paper, the authors outlined that Cause related marketing campaigns are categorized as one of the CSR initiatives. This study had been conducted for the cause related marketing initiatives of IDEA cellular which was targeted at the mobile users. The study concluded that the mobile users have appositive attitude towards cause brand alliance due to familiarity with an important social cause which had been promoted by IDEA through its ' $3 \mathrm{G}$ pe busy' campaign

Cosmina Paula (2012), in this paper the author investigated the link between individuals' expectations of corporate social responsibility (CSR) and their intention to support the socially responsible behaviour of companies. The results of the study showed that expectations of CSR tend to have a significant positive influence on the intended CSR support by customers. Many consumers were ready to put pressure on companies through boycotts, in order to convince them to be more socially responsible.

Salma KaremKolkailah, EhabAbouAish and Noha El-Bassiouny (2012), the research is aimed at studying the consumers' awareness of, their attitude and behavioural intentions towards socially responsible companies in the Egypian market. Exploratory qualitative interviews were conducted with corporate managers of a sample of five companies in the Egyptian market. The results revealed that consumers in Egypt were actually aware of the CSR concept and even tend to develop positive attitude towards socially responsible companies.

Yuan-Shuh Lii, Kuang-Wen Wu and May-Ching Ding (2013), in this study, the authors focused on the effect of the sustainable marketing of three types of corporate social responsibility initiatives-sponsorship, cause-related marketing, and philanthropy-on consumer evaluations with the moderating effect of psychological distance The variables used are perceived credibility of the campaign, attitudes toward the brand, extra-role behavior and purchase intention. The study highlighted the results that philanthropy was found to have a stronger effect on consumer evaluations, followed by sponsorship and cause-related marketing.

Lois A. Mohr, Deborah J. Webb and Katherine E. Harris (2001) in this paper the authors pointed out that companies are facing increasing pressure to both maintain profitability and behave in socially responsible ways, yet researchers have provided little information on how corporate social responsibility impacts profitability. The findings from in-depth interviews of consumers were to determine their views concerning the social responsibilities of companies

Marylyn Carrigan and Ahmad Attalla (2001), in this paper the author examined whether or not consumers care about ethical behaviour, and investigated the effect of good and bad ethical conduct on consumer purchase behaviour. This paper concluded by some thoughts on how marketers might encourage consumers to engage in positive purchase behaviour in favour of ethical marketing.

Bhattacharya C B and Shankar Sen. (2004), the authors stated that consumer reactions to CSR are not as straightforward and there are numerous factors that affect whether a firm's CSR activities translate into consumer purchases. The main findings of the study were that perceived interdependencies between product quality and CSR initiatives also affect consumers' intentions to purchase the company's products. Consumers' lack of awareness about CSR initiatives is a major limiting factor in their ability to respond to these initiatives. Companies therefore need to work on increasing awareness levels.

Geoffrey Williams and John Zink in (2008), this paper explored the relationship between attitudes to corporate social responsibility and the cultural dimensions of business activity identified by Hosted \& Hosted using a sample of nearly 90,000 stakeholders drawn from 28 countries. They showed that the propensity of consumers to punish firms for bad behaviour varies in ways that appear to relate closely to the cultural characteristics identified by Hosted.

Jorge E. Arafia and Carmelo J. Leon (2009), In this study the authors analysed the role of environmental performance in the profile of corporate social responsibility as perceived by consumers. The study focuses on three products namely, a) a pair of athletic shoes, b) a generic detergent and c) a generic pharmaceutical product. The results showed that the linear compensatory heuristic is the most extended across individuals and these subjects value most 
the policies concerned with environmental management.

Alan Anthony Pomering (2009), This study examined whether consumer skepticism toward the advertising of CSR claims can be influenced by altering the diagnosticity of social topic information and CSR commitment message dimensions. Data received via an online panel of a cross-section of 417 Australian consumers were analysed. The findings of this thesis provide evidence that consumers have the ability to deal with larger cognitive loads, created by information about specific impacts of firms' CSR programs, and that such diagnostic information is useful in reducing skepticism responses to CSR messages.

Alev Selbes and Samira Mohamed (2010), this paper focused mainly on the CSR activities of the cosmetics brands and how they affect consumer purchase behavior. Consumers find CSR an important topic in the cosmetics industry and would to like to see more socially responsible cosmetic brands. In this way, CSR activities contribute to the brand image while increasing the credibility of these activities in the consumers' mind. Moreover, it is necessary for the cosmetic brands to communicate their CSR activities to the consumers.

\section{Data Analysis}

The primary data collected through the questionnaire were scrutinized, and SPSS package was used to analyze the primary data. The following Statistical tools were used for this purpose in order to arrive the objectives of the study i.e., to identify the FMCGs consumers choice and awareness on CSR. And To study the influence of Demographic and the purchase details of FMCGs consumers on their CSR perception,

\section{$\checkmark$ Simple Percentage Analysis \\ $>$ T-Test \\ Factor Analysis \\ K-Means Cluster Analysis \\ 3.1 The Factors Influencing the Choice of FMCG product}

The important factors influencing the choice of FMCG products/brands are obtained from the customers through 13 variables in Likarts 5 point scale which ranges from very important to not at all important. In order to reduce these variables, the researcher applied the factor analysis by principal component method for grouping of variables and formation of new factors. The results of factor analysis, is presented below:

Table 1. KMO and Bartlett's test for choice of FMCG products

\begin{tabular}{lll}
\hline Kaiser-Meyer-Olkin Measure of Sampling Adequacy & $\mathbf{. 8 0 8}$ \\
\hline \multirow{3}{*}{ Bartlett's Test of Sphericity } & Approx. Chi-Square & 1547.267 \\
& df & 78 \\
& Sig. & .000 \\
\hline
\end{tabular}

From the above table, it is found that the KMO measure of sampling adequacy is 0.808 , Bartlett's Test of Sphericity with approximate chi-square value of 1547.267 is statistically significant at $5 \%$ level. This indicates the variables from the Normal Distribution and they can be grouped with appropriate variance. The individual variances are presented in the following Communalities table.

Table 2. Communalities for choice of FMCG products

\begin{tabular}{lll}
\hline & Initial & Extraction \\
\hline Product quality & 1.000 & .588 \\
Price & 1.000 & .505 \\
Brand name & 1.000 & .586 \\
Packaging & 1.000 & .626 \\
Accessibility & 1.000 & .615 \\
Varieties in the products & 1.000 & .433 \\
Product safety & 1.000 & .409 \\
The location of the store & 1.000 & .570 \\
Customer service & 1.000 & .704 \\
Atmosphere of the store/company & 1.000 & .599 \\
\hline
\end{tabular}




\begin{tabular}{lll}
\hline Product information & 1.000 & .638 \\
Company reputation & 1.000 & .514 \\
Companies CSR & 1.000 & .565 \\
\hline
\end{tabular}

\subsection{Extraction Method: Principal Component Analysis}

From the above table, it is found that the thirteen variables possess the variance ranging from .409 to .704 . This shows that the thirteen variables possess the variance 40.9 per cent to 70.4 per cent. The numbers of factors extracted are clearly presented in the following total variance table.

Table 3.Total variance explained for choice of FMCG products

\begin{tabular}{|c|c|c|c|c|c|c|c|}
\hline \multirow[b]{2}{*}{ Component } & \multicolumn{3}{|c|}{ Initial Eigenvalues } & \multirow[b]{2}{*}{ Cumulative \% } & \multicolumn{3}{|c|}{ Rotation Sums of Squared Loadings } \\
\hline & Total & $\begin{array}{l}\% \\
\text { Variance }\end{array}$ & of & & Total & $\begin{array}{ll}\% & \text { of } \\
\text { Variance } & \\
\end{array}$ & Cumulative \% \\
\hline 1 & 3.668 & 28.215 & & 28.215 & 2.735 & 21.039 & 21.039 \\
\hline 2 & 1.500 & 11.539 & & 39.754 & 1.792 & 13.786 & 34.825 \\
\hline 3 & 1.170 & 9.000 & & 48.754 & 1.546 & 11.893 & 46.718 \\
\hline 4 & 1.013 & 7.790 & & 56.544 & 1.277 & 9.826 & 56.544 \\
\hline 5 & .951 & 7.315 & & 63.859 & & & \\
\hline 6 & .748 & 5.753 & & 69.612 & & & \\
\hline 7 & .733 & 5.638 & & 75.250 & & & \\
\hline 8 & .678 & 5.213 & & 80.463 & & & \\
\hline 9 & .612 & 4.709 & & 85.172 & & & \\
\hline 10 & .564 & 4.338 & & 89.510 & & & \\
\hline 11 & .503 & 3.868 & & 93.378 & & & \\
\hline 12 & .453 & 3.485 & & 96.863 & & & \\
\hline 13 & .408 & 3.137 & & 100.000 & & & \\
\hline
\end{tabular}

\subsection{Extraction Method: Principal Component Analysis}

From the above table, it is found that the thirteen variables are reduced into 4 predominant factors with cumulative variance of $56.544 \%$. They individually possess the variances $21.039 \%, 13.786 \%, 11.893 \%$ and $9.826 \%$. It implies that the thirteen variables are reduced into 4 predominant factors.

Table 4. Rotated Component Matrix (a) for choice of FMCG products

\begin{tabular}{|c|c|c|c|c|}
\hline & \multicolumn{4}{|c|}{ Component } \\
\hline & 1 & 2 & 3 & 4 \\
\hline Q14.11 & .751 & & & \\
\hline Q14.13 & .726 & & & \\
\hline Q14.10 & .710 & & & \\
\hline Q14.12 & .693 & & & \\
\hline Q14.7 & .578 & & & \\
\hline Q14.5 & & .734 & & \\
\hline Q14.4 & & .711 & & \\
\hline Q14.6 & & .561 & & \\
\hline Q14.9 & & & .801 & \\
\hline Q14.8 & & & .668 & \\
\hline Q14.1 & & & & .756 \\
\hline Q14.3 & & & .432 & .536 \\
\hline Q14.2 & & & & .529 \\
\hline
\end{tabular}

\subsection{Extraction Method: Principal Component Analysis}

1) Rotation Method: Varimax with Kaiser Normalization.

a Rotation converged in 6 iterations. 
From the Rotated Component Matrix, it can be identified that the First factor consist of five variables, Product Information (.751), Companies CSR (.726), Atmosphere of the store/company (.710), Company Reputation(.693) and Product Safety (.578).

The second factor consists of three variables, Accessibility (.734), Packaging (.711) and Varieties in the product (.561). As these three variables makes the consumer become choosy, hence, this factor is said to be named as "Product Discretionary Attributes".

The third factor consists of two variables customer service (.801) and the location of the store (.668). The above-said variables related to the company/store, therefore, this factor extracted can be labelled as "Company-specific Attributes".

The fourth factor consists of three variables, Product quality (.756), Brand Name (.536) and Price (.529). It is clear that the consumers purchase FMCGs by evaluating the above-said variables, Hence this factor extracted can be denoted as "Product Evaluation Attributes".

2). Classification of respondents with respect to the factors influencing choice of FMCG product

The factor analysis by principal component method, classified the sample unit into four pre-dominant factors namely Affective Identification attributes, Product Discretionary attributes, Company-specific attributes and Product evaluation attributes.

Now this factors act as a basis to classify the sample unit into heterogeneous groups. These groups are heterogeneous in nature. Therefore, researcher applied K-Means Cluster Analysis and the following results were obtained.

Table 5. Final cluster centers of choice of FMCGs

\begin{tabular}{|c|c|c|c|c|}
\hline \multirow[b]{2}{*}{ S. No. } & \multirow{2}{*}{ Particulars } & \multicolumn{3}{|c|}{ Clusters } \\
\hline & & $\mathbf{I}$ & II & III \\
\hline 1 & Affective Identification attributes & .42589 & -1.79414 & .15160 \\
\hline 2 & Product Discretionary attributes & .53629 & .13550 & -.98725 \\
\hline 3 & Company-specific attributes & .11822 & .54284 & -.47000 \\
\hline 4 & Product Evaluation attributes & .24391 & .02562 & -.43130 \\
\hline
\end{tabular}

Table 6. Number of cases in each cluster of choice of FMCGs

\begin{tabular}{lll}
\hline Clusters & Frequency & Percentage \\
\hline I & 321.000 & 53.50 \\
II & 92.000 & 15.33 \\
III & 187.000 & 31.17 \\
Total & $\mathbf{6 0 0 . 0 0 0}$ & $\mathbf{1 0 0 . 0 0}$ \\
\hline
\end{tabular}

From the above table, it is found that the first cluster consist of $321(53.50 \%)$ consumers who agree with the importance of affective identification attributes, product Discretionary attributes, very moderately agree the Company-specific attributes and Product evaluation attributes. As this group of consumers are very sentimental towards the products they purchase and they are very choosy in purchasing the FMCG products, this group of consumers can be labelled as "Fastidious consumers".

The second cluster consists of $92(15.33 \%)$ consumers who give importance to Company-specific attributes and less importance to product discretionary attributes and product evaluation attributes and poor importance to affective identification attributes can be named as "Indifferent Consumers" as they are not sentimental towards the products.

The third cluster consists of 187 (31.17\%) who give less importance to Affective identification attributes and very less importance to Product Discretionary attributes, Company-specific attributes and Product attractiveness attributes. The consumers of this group are less sentimental and they are not choosy when they purchase the product hence, this group of consumers can be labelled as "Tranquil Consumers".

3). Consumer Awareness on Corporate Social Responsibility

Perception on CSR Practices of FMCG companies 
FMCG companies are doing different CSR practices. Hence, it is essential to find out which practices influence the most the consumers of FMCGs. In order to find out the level of importance of CSR practices of FMCG companies, T-test was applied and the results were given below.

Table 7. One-Sample statistics for the perception on CSR Practices of FMCG companies

\begin{tabular}{lllll}
\hline Particulars & N & Mean & Std. Deviation & Std. Error Mean \\
\hline Healthcare & 600 & 4.4767 & .84695 & .03458 \\
Education & 600 & 4.2517 & .82023 & .03349 \\
Disaster Relief & 600 & 4.0350 & .96367 & .03934 \\
Community Welfare & 600 & 3.8367 & 1.03688 & .04233 \\
Environment & 600 & 4.1333 & .96459 & .03938 \\
Rural Development & 600 & 3.8600 & 1.03868 & .04240 \\
Animal welfare & 600 & 3.4317 & 1.18364 & .04832 \\
Any other practices ........ (specify) & 600 & 1.4167 & 1.79957 & .07347 \\
\hline
\end{tabular}

The above table indicated that the mean values of variables relating to opinion on the level of importance of CSR Practices of FMCG Companies ranges from 4.476 to 3.74 and the standard deviation varied from 0.96 to 1.79 respectively. The following table describes the computation of one-sample t-test.

Table 8. One-Sample T-test for the perception of CSR Practices of FMCG Companies

\begin{tabular}{|c|c|c|c|c|c|c|}
\hline \multirow[b]{3}{*}{ Particulars } & \multicolumn{6}{|c|}{ Test Value $=\mathbf{3}$} \\
\hline & \multirow{2}{*}{$\begin{array}{l}\text { t } \\
\text { Lower }\end{array}$} & \multirow{2}{*}{$\begin{array}{l}\text { df } \\
\text { Upper }\end{array}$} & \multirow{2}{*}{$\begin{array}{l}\text { Sig. } \\
\text { (2-tailed) } \\
\text { Lower }\end{array}$} & \multirow{2}{*}{$\begin{array}{l}\text { Mean } \\
\text { Difference } \\
\text { Upper }\end{array}$} & \multicolumn{2}{|c|}{$\begin{array}{l}95 \% \text { confidence interval } \\
\text { of the difference }\end{array}$} \\
\hline & & & & & Lower & Upper \\
\hline Healthcare & 42.707 & 599 & .000 & 1.47667 & 1.4088 & 1.5446 \\
\hline Education & 37.379 & 599 & .000 & 1.25167 & 1.1859 & 1.3174 \\
\hline Disaster Relief & 26.308 & 599 & .000 & 1.03500 & .9577 & 1.1123 \\
\hline Community Welfare & 19.765 & 599 & .000 & .83667 & .7535 & .9198 \\
\hline Environment & 28.780 & 599 & .000 & 1.13333 & 1.0560 & 1.2107 \\
\hline Rural Development & 20.281 & 599 & .000 & .86000 & .7767 & .9433 \\
\hline Animal welfare & 8.933 & 599 & .000 & .43167 & .3368 & .5266 \\
\hline Any other practices ...... (specify) & -21.552 & 599 & .000 & -1.58333 & -1.7276 & -1.4390 \\
\hline
\end{tabular}

It is found from the above table that the eight t-test values of opinion on the level of importance of CSR Practices of FMCG companies, Healthcare $(\mathrm{t}=42.707, \mathrm{p}=0.000)$, Education $(\mathrm{t}=37.379, \mathrm{p}=0.000)$, Disaster Relief $(\mathrm{t}=26.308, \mathrm{p}=0.000)$, Community Welfare $(\mathrm{t}=19.765, \mathrm{p}=0.000)$, Environment $(\mathrm{t}=28.780, \mathrm{p}=0.000)$, Rural Development $(\mathrm{t}=20.281, \mathrm{p}=0.000)$, Animal Welfare $(\mathrm{t}=8.933, \mathrm{p}=0.000)$, and any other practices such as helping the Physically Challenged, Mentally Retarded Persons etc., $(\mathrm{t}=11.805, \mathrm{p}=0.000)$, are statistically significant at 5 percent level.

The T-Test denotes that the respondents gave very much importance to the Healthcare practices, Education, Disaster Relief, and the Environment; they gave moderate importance to the Community welfare, Rural Development and Animal Welfare and they gave very less importance to the any other practices such as minorities welfare, women empowerment etc., To conclude, The consumers in Tamil Nadu expected the CSR Practices in the domain of Healthcare, Education and Environment.

\section{Factors Influencing Perception on Buycott Decisions}

The important factors influencing the Perception on Purchase Decision on Buycott decision) are obtained from the customers through eighteen variables in Likarts 5 point scale which ranges from very important to not at all important. In order to reduce these variables, the researcher applied the factor analysis by principal component method for grouping of variables and formation of new factors. The results of factor analysis, is presented below: 
Table 9. KMO and Bartlett's test for Buycott

\begin{tabular}{lll}
\hline Kaiser-Meyer-Olkin Measure of Sampling Adequacy. & .872 \\
\hline Bartlett's Test of Sphericity & Approx. Chi-Square & 2926.311 \\
& df & 153 \\
& Sig. & .000 \\
\hline
\end{tabular}

From the above table, it is found that the KMO measure of sampling adequacy is 0.872 , Bartlett's Test of Sphericity with approximate chi-square value of 2926.311 is statistically significant at $5 \%$ level. This indicates that the variables form the Normal Distribution and they can be grouped with appropriate variance. The individual variances of opinion on Buycott are presented in the following Communalities table.

Table 10. Communalities for consumer perception on Buycott

\begin{tabular}{|c|c|c|}
\hline & Initial & Extraction \\
\hline $\begin{array}{l}\text { I buy products from the FMCGs company which conducts social responsibility } \\
\text { initiatives. }\end{array}$ & 1.000 & .596 \\
\hline I would pay more to buy products from a socially responsible FMCG company. & 1.000 & .569 \\
\hline $\begin{array}{l}\text { If the price and quality of two products are the same, I would buy from the } \\
\text { FMCG that has socially responsible reputation. }\end{array}$ & 1.000 & .513 \\
\hline $\begin{array}{l}\text { I believe that it is important to examine company CSR strategies when I } \\
\text { purchase. }\end{array}$ & 1.000 & .649 \\
\hline $\begin{array}{l}\text { A high CSR rating of FMCG company will make a positive impression on me } \\
\text { to purchase the product. }\end{array}$ & 1.000 & .505 \\
\hline I will make some changes in behavior for social responsibility. & 1.000 & .379 \\
\hline I tend to repurchase products from socially responsible FMCG companies. & 1.000 & .491 \\
\hline $\begin{array}{l}\text { I purchase the products from the FMCG companies which have used } \\
\text { environmentally friendly packages. }\end{array}$ & 1.000 & .510 \\
\hline $\begin{array}{l}\text { I will purchase the products of FMCG which contain environment quality } \\
\text { marks on the label of the product. }\end{array}$ & 1.000 & .587 \\
\hline $\begin{array}{l}\text { I usually buy products which gives correct and full information on the label of } \\
\text { the products. }\end{array}$ & 1.000 & .378 \\
\hline $\begin{array}{l}\text { I am ready to switch over to another product of FMCG which engaged in social } \\
\text { activities. }\end{array}$ & 1.000 & .500 \\
\hline I buy products from the FMCG company which publishes CSR reporting. & 1.000 & .420 \\
\hline I consider the ethical reputation of FMCGs when I shop. & 1.000 & .476 \\
\hline $\begin{array}{l}\text { I will convince somebody to buy the products of FMCG which engaged in CSR } \\
\text { activities. }\end{array}$ & 1.000 & .504 \\
\hline $\begin{array}{l}\text { I will punish the unethical FMCG company by not buying the products of the } \\
\text { company. }\end{array}$ & 1.000 & .592 \\
\hline $\begin{array}{l}\text { Negative news about a product of FMCG will impact on negative purchase } \\
\text { behaviour. }\end{array}$ & 1.000 & .545 \\
\hline $\begin{array}{l}\text { I will not purchase a socially irresponsible FMCG product, even with an } \\
\text { additional thing for free. }\end{array}$ & 1.000 & .633 \\
\hline I consider myself a socially conscious and responsible consumer. & 1.000 & .625 \\
\hline
\end{tabular}

\subsection{Extraction Method: Principal Component Analysis}

From the above table, it is found that the eighteen variables possess the variance ranging from .378 to .649 . This shows that the eighteen variables possess the variance 37.8 per cent to 64.9 per cent. The numbers of factors 
extracted are clearly presented in the following total variance table.

Table 11. Total variance explained for consumer perception on Boycott

\begin{tabular}{|c|c|c|c|c|c|c|}
\hline \multirow[b]{2}{*}{ Component } & \multicolumn{3}{|c|}{ Initial Eigenvalues } & \multicolumn{3}{|c|}{ Rotation Sums of Squared Loadings } \\
\hline & Total & $\begin{array}{ll}\% & \text { of } \\
\text { Variance } & \\
\end{array}$ & Cumulative $\%$ & Total & $\begin{array}{ll}\% & \text { of } \\
\text { Variance } & \\
\end{array}$ & Cumulative \% \\
\hline 1 & 5.274 & 29.297 & 29.297 & 3.030 & 16.835 & 16.835 \\
\hline 2 & 2.013 & 11.184 & 40.481 & 2.404 & 13.355 & 30.190 \\
\hline 3 & 1.151 & 6.394 & 46.875 & 2.207 & 12.259 & 42.449 \\
\hline 4 & 1.035 & 5.751 & 52.626 & 1.832 & 10.177 & 52.626 \\
\hline 5 & .947 & 5.264 & 57.890 & & & \\
\hline 6 & .871 & 4.840 & 62.729 & & & \\
\hline 7 & .762 & 4.232 & 66.961 & & & \\
\hline 8 & .739 & 4.105 & 71.066 & & & \\
\hline 9 & .682 & 3.787 & 74.853 & & & \\
\hline 10 & .637 & 3.538 & 78.390 & & & \\
\hline 11 & .614 & 3.413 & 81.803 & & & \\
\hline 12 & .539 & 2.995 & 84.799 & & & \\
\hline 13 & .527 & 2.927 & 87.726 & & & \\
\hline 14 & .502 & 2.788 & 90.513 & & & \\
\hline 15 & .485 & 2.695 & 93.208 & & & \\
\hline 16 & .468 & 2.601 & 95.809 & & & \\
\hline 17 & .415 & 2.304 & 98.113 & & & \\
\hline 18 & .340 & 1.887 & 100.000 & & & \\
\hline
\end{tabular}

\subsection{Extraction Method: Principal Component Analysis}

From the above table, it is found that the eighteen variables are reduced into four predominant factors with cumulative variance of $52.626 \%$. They individually possess the variances of $16.835 \%, 13.355 \%, 12.259 \%$ and $10.177 \%$. It implies the eighteen variables are reduced into four predominant factors.

Table 12. Rotated component matrix (a) for consumer perception on Buycott

\begin{tabular}{lllll}
\hline & Component & & \\
& $\mathbf{1}$ & $\mathbf{2}$ & $\mathbf{3}$ & $\mathbf{4}$ \\
\hline Q21BUY4 & .776 & & & \\
Q21BUY1 & .750 & & & \\
Q21BUY2 & .730 & & & \\
Q21BUY3 & .682 & & & \\
Q21BUY5 & .532 & & & \\
Q21BUY15 & & .697 & & \\
Q21BUY14 & & .635 & & \\
Q21BUY13 & & .627 & & \\
Q21BUY11 & & .598 & & \\
Q21BUY12 & & .416 & & \\
Q21BUY9 & & & .697 & \\
Q21BUY8 & & & .665 & \\
Q21BUY7 & & .417 & .535 & \\
Q21BUY10 & & & .485 & \\
Q21BUY6 & & & .425 & \\
Q21BUY18 & & & & \\
Q21BUY17 & & & \\
Q21BUY16 & & & & \\
\hline
\end{tabular}




\subsection{Extraction Method: Principal Component Analysis}

Rotation Method: Varimax with Kaiser Normalization.

\section{A Rotation converged in 6 iterations}

From the Rotated Component Matrix, it can be identified that the First factor consist of five variables, it is important to examine company CSR strategies when the consumer purchase (.776), I buy from the FMCG companies which conducts social responsibility (.750), would pay more to buy products from a socially responsible FMCG company (.730), if the price and quality of two products are the same I would buy from the socially responsible company(.682), and a high CSR rating of the FMCG company will make a positive impression to purchase the product (.532). These five variables describe how the CSR got momentum to consumer behaviour. Therefore, this factor extracted can be labelled as "CSR Performance Behaviour".

The second factor consists of five variables, I will punish the unethical FMCG company by not buying the products of the company (.697), I will convince somebody to buy the products of FMCG which engaged in CSR activities (.635), I consider the ethical reputation of FMCGs when I shop (.627), I am ready to switch over to another product of FMCG which engaged in social activities (.598), and I buy products from the company which publishes CSR reporting (.416). In this case, the consumers gave some rewarding attitude to the socially responsible FMCG companies like convincing somebody to buy the particular company product, switching behaviour for social responsibility, considering the socially responsible FMCG companies. Hence, this factor grouped can be named as "CSR variables. Hence, this factor grouped can be called as "Dogmatic Social Behaviour".

\section{Classification of Respondents with Respect to the Factors Influencing Boycott}

The factor analysis by principal component method, classified the sample unit into four pre-dominant factors namely, CSR Performance Behaviour, CSR Rewarding Behaviour, CSR Extended Behaviour, Dogmatic Social Behaviour. Now this factors act as a basis to classify the sample unit into heterogeneous groups. These groups are heterogeneous in nature. Therefore, researcher applied K-Means Cluster Analysis and the following results were obtained.

Table 13. Final cluster centres of Boycott

\begin{tabular}{|c|c|c|c|c|}
\hline \multirow[t]{2}{*}{ S. No. } & \multirow{2}{*}{ Particulars } & \multicolumn{3}{|l|}{ Clusters } \\
\hline & & $\mathbf{I}$ & II & III \\
\hline 1 & CSR Performance Behaviour & -1.74080 & .21915 & .53825 \\
\hline 2 & CSR Rewarding Behaviour & -.30524 & .22908 & -.10904 \\
\hline 3 & CSR Extended Behaviour & -.16088 & .50733 & -.46994 \\
\hline 4 & Dogmatic Social Behaviour & .21913 & -.61537 & .55938 \\
\hline
\end{tabular}

Table 14. Number of cases in each cluster of Boycott

\begin{tabular}{lll}
\hline Clusters & Frequency & Percentage \\
\hline I & 106.000 & 17.67 \\
II & 255.000 & 42.50 \\
III & 239.000 & 39.83 \\
Total & $\mathbf{6 0 0 . 0 0 0}$ & $\mathbf{1 0 0 . 0 0}$ \\
\hline
\end{tabular}

From the above table, it is found that the first cluster consist of $106(17.67 \%)$ of the consumers who strongly disagree with the CSR performance behaviour, CSR rewarding behaviour, and CSR extended behaviour and agree with the Dogmatic Social Behaviour. This group of consumers are not interested in the CSR related behaviour but they showed their rigidity in social behaviour. Therefore, this group of consumers can be labelled as "Antagonistic Consumers".

The second cluster consists of 255 (42.50\%) consumers who agree with the CSR performance behaviour, and CSR rewarding behaviour, strongly agree with the CSR extended behaviour, but strongly disagree with the Dogmatic social behaviour. This group of consumers dedicated their positive behaviour towards the CSR related issues, as they are activist to reward for social responsibility. Therefore this group of consumers can be categorised as "Bright spark Consumers". 
The third cluster consists of $239(39.83 \%)$ of the respondents who strongly agree with the CSR performance behaviour and Dogmatic Social behaviour, but disagree with the CSR rewarding behaviour and CSR extended behaviour. This group of consumers are socially conscious consumers but they do not reward for socially responsible companies. Hence, this group of respondents can be named as "Single-minded Consumers".

\section{Discussions Concluding Remark and Implications for the Study}

It is found that the sample unit of respondents consists of a maximum of 42.30 per cent of Urban consumers of FMCGs and a minimum of 28.20 per cent of Rural consumers; a maximum of 54.50 per cent of consumers are Male and followed by 45.50 per cent of the respondents are female consumers; a maximum of 53.80 per cent of consumers are in the age group 26-35. A minimum of 4.80 per cent of consumers are in the age group of Above 55. A maximum of 55.30 per cent of consumers are married and 44.70 per cent are unmarried. A maximum of 45.50 per cent of the respondents are Post Graduates and a minimum of only 8.80 per cent of the respondents' education represented by other qualifications such as Diploma, M.Phil., Ph.D holders etc., It is clear that a maximum of 53.20 per cent of the respondents' family are Joint Family and a minimum of 46.80 per cent are from Nuclear family.

From this analysis it is clear that the factors of choice of FMCGs differ significantly. Hence, the null hypothesis is rejected. Factor analysis concludes that the consumers purchase FMCGs because of Affective identification attributes which sentimentally impact the consumer to purchase FMCGs. And it is found that the first cluster consist of $321(53.50 \%)$ consumers who agree with the importance of affective identification attributes, product Discretionary attributes, very moderately agree the Company-specific attributes and Product evaluation attributes. As this group of consumers are very sentimental towards the products they purchase and they are very choosy in purchasing the FMCG products, this group of consumers can be labelled as "Fastidious consumers". The second cluster consists of $92(15.33 \%)$ consumers can be named as "Indifferent Consumers" as they are not sentimental towards the products. The third cluster consists of 187 (31.17\%) The consumers of this group are less sentimental and they are not choosy when they purchase the product hence, this group of consumers can be labelled as "Tranquil Consumers".

From this analysis it is clear that the factors influencing Perception on Boycott Decisions differ significantly. Hence, the null hypothesis is rejected. Factor analysis concludes that the consumers who aware about CSR showed their positive purchase behaviour by way of CSR Performance Behaviour, CSR Rewarding Behaviour, CSR Extended Behaviour, Dogmatic Social Behaviour. It is found that the first cluster consist of $106(17.67 \%)$ of the consumers who are not interested in the CSR related behaviour but they showed their rigidity in social behaviour. Therefore, this group of consumers can be labelled as "Antagonistic Consumers". The second cluster consists of $255(42.50 \%)$ consumers dedicated their positive behaviour towards the CSR related issues, as they are activist to reward for social responsibility. Therefore this group of consumers can be categorised as "Bright spark Consumers". The third cluster consists of 239 (39.83\%) of the respondents are socially conscious consumers but they do not reward for socially responsible companies. Hence, this group of respondents can be named as "Single-minded Consumers".

The consumers of FMCG, purchase products based on the quality, brand name, customer service etc., they have given less moderate importance to the Company CSR. This is because of either lack of awareness on CSR. Hence, advertisements may be given to increase the awareness level. The CSR activities done by the companies may be given on the label of the product attractively. Over the past decade, corporate social responsibility has gained attention as it is considered as the new weapon in the business arena. Societal problems cannot be solved only by the Government itself. As Business organization gets everything from the society, hence, it is the duty of the company to return something back to the society. Even though, CSR is considered as a marketing strategy, it is considered as a tool to get profit etc., it has some unripe benefit from it. It is the need of the hour for the developing countries like India. Though the Indian Government has made mandatory the CSR Provisions, it has not reached even to the middle people. There has been wider scope for further research in this research. Future Research can be done on other industries like capital goods industry, sports goods, consumer and company identification with CSR, CSR with brand equity, competitive advantage.

\section{References}

Alan, P., \& Sara, D. (2009). Assessing the Prerequisite of Successful CSR Implementation: Are Consumers Aware of CSR Initiatives? Journal of Business Ethics, 85, 285-301. https://doi.org/10.1007/s10551-008-9729-9

Alex, W. (2009). Perceptions of Corporate social Responsibility practices on Mobile Phone Companies. International Journal of Mobile Marketing, 4(1), 62-68. 
Alex, W., \& Ronald, B. A. (2011). A Multi-Staged Model of Consumer Responses to CSR Communications. The Journal of Corporate Citizenship, 41.

Andrea, J. S. S., May, O. L., \& Patrick, E. M. (2011). Consumer perceptions of the Antecedents and Consequences of Corporate Social Responsibility. Journal of Business Ethics, 102(1), 47-55. https://doi.org/10.1007/s10551-011-0904-z

Cosmina, P. (2012). Influence of Consumers' Expectations regarding CSR on their intention to support a company's socially responsible behavior during the crisis. Revista Economica, 3, 187-194.

Dale, W. R., \& Cristel, A. R. (2010). Here or There? Consumer reactions to Corporate Social Responsibility Initiatives: Egocentric tendencies and their moderators. Marketing Letters, 21, 65-81.

Elias, G. R. (2012). Brand-Consumer Relationship and Corporate Social Responsibility: Myth or Reality \& Do Consumers really care? Journal of Business \& Economic Research, 10(6), 333-343. https://doi.org/10.19030/jber.v10i6.7024

Flavio, B., \& Virginia, S. (2012). Corporate Social Responsibility: An Analysis on Consumer Perception. Journal of Agricultural Science and Technology, 2, 1119-1125.

Geoffrey, W., \& John, Z. (2008). The effect of culture on consumers' willingness to punish irresponsible corporate behavior: Applying Hofstede's typology to the punishment aspect of corporate social responsibility. Business Ethics: A European Review, 17(2), 210-226. https://doi.org/10.1111/j.1467-8608.2008.00532.x

Imran, A., Kashif, U. R., Ayse, K. Y., Sajid, N., \& Jawaria, F. A. (2010). Effects of Corporate Social Responsibility on Consumer retention in Cellular industry of Pakistan. African Journal of Business Management, 4(4), 475-485.

Iza, G. (2012). Impact of Corporate Social Responsibility on Consumer Purchase Decision. American-Eurasian Journal of Scientific Research, 7(5), 207-211. https://doi.org/10.5829/idosi.aejsr.2012.7.5.1110

Jayakumar, A., \& Geetha, K. (2012). CSR - A key ingredient for Corporate Sustainability. Indian Economic Panorama, 20(3A), 42-45.

Jayakumar, A., \& Geetha, K. (2013). Financial Inclusion as a Corporate Social Responsibility- A way for rural development. Indian Economic Panorama, 22(3A), 38-41.

Jaywant, S., Maria, D. M. G., De los, S. S., \& Ignacio, R. D. B. (2008). Understanding Corporate Social Responsibility and Product perceptions in Consumer Markets: A Cross-Cultural Evaluation. Journal of Business Ethics, 80, 597-611. https://doi.org/10.1007/s10551-007-9457-6

Jorge, E. A., \& Carmelo, J. L. (2009). The Role of Environmental Management in Consumers Preferences for Corporate Social Responsibility. Environ Resource Econ, 44, 495-506. https://doi.org/10.1007/s10640-009-9297-1

Jorge, M. V., Rafael, B., \& Jose, M. P. (2011). The Influence of Corporate Social Responsibility and Price Fairness on Customer Behaviour: Evidence from the Financial Sector. Corporate Social Responsibility and Environmental Management, 18, 317-331. https://doi.org/10.1002/csr.247

Khaled, A., \& Fares, J. H. A. S. (2012). Corporate social responsibility associated with Customer Satisfaction and Financial Performance a case study with Housing Banks in Jordan. International Journal of Humanities and Social Science, 2(15), 102-115.

Ki-Han, C., Ji-Eun, Y., Myeong-Guk, C., \& Shin, J. I. (2013). The Effects of CSR on Customer Satisfaction and Loyalty in China: The Moderating Role of Corporate Image. Journal of Economics, Business and Management, 3(5), 542-547.

Longinos, M., \& Salvador, R. (2007). I Need You Too!" Corporate Identity Attractiveness for Consumers and The Role of Social Responsibility. Journal of Business Ethics, 71, 245-260. https://doi.org/10.1007/s10551-006-9137-y

Longinos, M., Salvador, R., \& Alicia, R. (2009). The Role of Identity Salience in the Effects of Corporate Social Responsibility on Consumer Behaviour. Journal of Business Ethics, 84, 65-78. https://doi.org/10.1007/s10551-008-9673-8

Lu, Z., \& Mary, A. G. (2011). Corporate Social Responsibility, Applicants' Individual Traits, and Organisational Attraction: A Person - Organisation Fit Perspective. Journal of Business and Psychology. 
Marylyn, C., \& Ahmad, A. (2001). The myth of the ethical consumer - do ethics matter in purchase behavior. Journal of Consumer Marketing, 18(7), 560-577. https://doi.org/10.1108/07363760110410263

\section{Copyrights}

Copyright for this article is retained by the author(s), with first publication rights granted to the journal.

This is an open-access article distributed under the terms and conditions of the Creative Commons Attribution license (http://creativecommons.org/licenses/by/4.0/). 